\title{
Epilogue on global consumer culture: epistemology and ontology
} Introduction

The purpose of the conceptual paper entitled "Global Consumer Culture: Epistemology and Ontology" was to propose a conceptual framework that highlights the renewing and reinforcing nature of global consumer culture (GCC). In doing so, the paper describes four facets of GCC (i.e. consumer acculturation, deterritorialization, cultural and geographic-specific entities, and global cultural flows) in a vortex-like manner, along with five distinct consumer responses to GCC (i.e. assimilation, separation, marginalization, glocalization and creolization). A major premise of this work is that: research needs to move away from the global-local dichotomy and should instead understand GCC as a set of "various GCC subcultures shaped to varying degrees by local, ethnic, and other particularized cultural narratives" (Cleveland and Bartsch, 2019); and that GCC is moving away from being predominantly Western in flavor, but increasingly shifts from West to East, as Eastern societies enjoy the benefits of economic growth and plug into the global economy.

To challenge and expand on our thoughts, several eminent Scholars in the domain of GCC were invited to offer their thoughts on our propositions. To this end, de Mooij (2019), Torelli and Stoner (2019) and Magnusson and Westjohn (2019) have offered thoughtful pieces that complement and extend our work. We would like to take the opportunity to thank them for their excellent comments. Here, we take the time to respond to their propositions. In what follows, we briefly summarize each comment and discuss their propositions in light of our work on "Global Consumer Culture: Epistemology and Ontology."

\section{Marieke de Mooij - "Fairy tales of global consumer culture in a polarizing world"}

De Mooij's commentary on the Cleveland and Bartsch's (2019) paper claims to emphatically disagree with the perspectives offered by these authors, although a closer look reveals that numerous dissenting assertions do not contradict, but actually, are in sync with our propositions. The notion that GCC is overwhelmingly North American in origin is indeed outdated, and the likelihood of a resurgence of nationalism and other particularized/placebased identities in response to globalization does not contradict GCC; on the contrary, these reactions are occurring partly because of GCC.

First, as noted in our paper, "[w]e predict that the constituents for GCC will progressively shift from West to East, as the planet' s relative economic epicenter once again swings back to the Orient (The Economist, 2018) even as Asian cultures themselves are transmuting because of globalization." A recent article in the Economist (2018), under the title "The Chinese Century: Well Under Way" reiterates this, contending that "[a]lthough America remains the lone superpower, China has already replaced it as the driver of global change" (p. 85).

Second, we believe that national cultures, while important, are overexposed as the primary basis for distinguishing international marketing segments, whereas cultural and identity-related dispositions at levels above and below that of the nation-state are woefully underrepresented, including distinct cultural regions and ethnic tribes within countries (e.g. French-speaking Canada, Aboriginals), groups and regions spanning nation-states (e.g. Basque country, Kurds), coherent cultural aspects shared at the continental and sub-continental levels (e.g. the Arab World, Latin America and Mediterranean), as well as ethnic diasporas (e.g. overseas Chinese, Jews and Armenians).

Third, with respect to characterizing GCC as representing fairy tales, national cultures Vol. 36 No. 4, 2019 pp. $598-606$

C) Emerald Publishing Limited $0265-1335$ 
expressive narrative), about a homeland's past that is based partly on truth, partly on myth and most likely a mishmash of both. As Renan (1882/2002, p. 50) famously stated, "forgetting, and, I would even say, historical error are an essential factor in the creation of a nation." Often these narratives contain aspects appropriated from a bricolage of traditions partly derived from other places, which over time are collated, transmuted and imbued with a veneer of uniqueness. At the highest level of abstraction, folklore comprises "a body of knowledge, a mode of thought, or a kind of art" (Ben-Amos, 1971, p. 5), is "very much an organic phenomenon" (p. 4), and one that is shaped by the "social context, the cultural attitude, the rhetorical situation, and the individual aptitude" (p. 4). As Ben-Amos (1971) concludes, "the materials of folklore are mobile, manipulative, and transcultural" (p. 4).

To varying degrees across time and place - and, often by force or other means of coercion (Renan, 1882/2002) - political, educational, religious, broadcast media and other state institutions have been and continue to be involved in nation building.[1] Minimizing the unprecedented movements of people across frontiers, and disregarding the roles played by transnational, media, institutions, factions and brands nowadays, is tantamount to ignoring the "elephant in the room." Cultures change from within and without, due to internal pressures and external forces. Arguably, more than in any prior historical period, those external forces are to a greater or lesser extent buffeting individuals and societies around the world. These include capital and media flows, resource shortages and environmental degradation, and even ideas, such as neoliberalism (i.e. laissez-faire economic liberalism) and the emancipation of women. We submit that the notion of GCC is no less plausible than that of corporate culture, European culture, Western culture, Ancient Roman culture, or perhaps even, American culture.

Consider just one of the numerous forces driving GCC described in the literature: the unprecedented population exchanges across borders that have occurred over the past few decades. These movements of people across borders undermines Levitt's (1983) prediction of the progressively culturally homogeneous world, which for the most part is a vision that we do not share. Take, for example:

- the Chinese diaspora, which numbers more than 50m ethnic Chinese living outside of Greater China (PRC, Hong Kong, Taiwan, etc.)[2], with at least a million ethnic Chinese living on each of every continent;

- metropolitan Toronto, with $2.7 \mathrm{~m}$ foreign-born, or 46 percent of the population[3];

- the United Arab Emirates and its principal city of Dubai (where, 71 and 85 percent of the population, respectively, are expatriates from many (and mostly) Asian countries[4]);

- the USA, which, according to census projections, is projected to become a "minority white" country in 2045[5];

- and even Russia which, after years of falling population (and despite having a death rate equal to its birth rate), once again has robust demographic growth due to high immigration levels, with the country presently housing nearly $11 \mathrm{~m}$ foreigners, according to UN estimates[6].

Clearly, these and many other places are becoming more heterogeneous within - but at the same time, this diffusion foments cultural exchanges, encouraging to some extent, if only for certain consumption contexts, episodes of behavioral uniformity across boundaries.

None of what is written above indicates that nations and national cultures are obsolete. However, these observations do raise the issue of whether international marketers should continue to rely, so heavily, on nations as core defining units, together with their corresponding national indices (e.g. Hofstede, 2001), as focal entities for developing 
IMR

36,4

600

marketing strategies. The latter question is important given these indices' high levels of aggregation (see Brewer and Venaik, 2012; Venaik and Brewer, 2013 for critiques). The national focus is usually undertaken in order to account for cultural differences among consumers in different places: yet, since culture is a precursor of thought and behavior (Berry, 1997), to model cultural processes (including GCC) accurately, thoughts and behaviors should be measured at the level of the individual consumer (McSweeney, 2013).

We repeatedly reiterate in our entire discourse that researchers must move away from the false dichotomy of globalization vs localization, and they must discard outdated notions of globalization essentially entailing Americanization. Our paper describes five different consumer responses to globalization, of which only one implies strict assimilation. Contrary to championing Levitt's (1983) position, the latter response is one that we largely discredit given that perceived cultural encroachment stimulates separation (resistance to GCC), marginalization (eschewing cultural traditions as well as global alternatives), glocalization (the mingling and indigenization of global ingredients with local flavors) and creolization (the fusion over time of discrete and glocalized cultural elements into a new cultural entity which is then disseminated). It is the final pattern which leads us to postulate the emergence of several GCC transfigurations, which, to varying degrees (across place, person and time), will coexist alongside (and sometimes conflict with) cultures and identities rooted in ethnic, tribal, national and other territorially based identities, as well as other identities deriving from one's occupation, gender, lifestyle, generation and so forth.

\section{Carlos J. Torelli and Jennifer Stoner - "Global Consumer Culture: Consequences for Consumer Research"}

With their reflections on the mingling of cultural identities, blurred boundaries of brand ownership and the emergence of multicultural spaces in contemporary societies, Torelli and Stoner (2019) provide timely extensions to our framework and offer critical ramifications of the various psychological responses of consumers to globalization. In doing so, they provide a roadmap for future investigations into the perceptual, cognitive, motivational and psychological consequences of globalization.

The task of building a truly global brand from scratch is highly challenging, time-consuming and resource-intensive. Instead of the traditional market development strategy (whereby existing brands are launched in new markets), many companies are internationalizing their brands by swifter avenues, by acquiring foreign brands, associated distribution channels and technological and marketing know-how. Torelli and Stoner (2019) explain this clearly with their examples of how the Tata Group of India obtained Britain's Jaguar and Land Rover brands, and how China's Lenovo purchased IBM's PC division.

The same global brands are appealing to global, glocal and even local market segments, often for different motives. These reasons vary, ranging from the utilitarian considerations of perceived higher quality and reliability, as well as potentially lower prices that ensue from brand economies of scale, to the hedonic, esteem and value-expressive considerations of enhanced social status, prestige and sophistication, accorded to the purchaser. In other circumstances, local alternatives may be alluring to these same segments, again for different reasons. The advantages proffered by indigenous brands are numerous, including greater responsiveness to cultural sensitivities and domestic preferences, as well as the pride that accompanies the consumption of brands that express affiliation to one's in-group and support one's own economy (Winit et al., 2014; Özsomer, 2012; Dimofte et al., 2008; Schuiling and Kapferer, 2004). Moreover, domestic and cosmopolitan consumers similarly value the fact that these brands can offer cultural heritage and authenticity (Cleveland and Laroche, 2012). When pursuing global market segments (i.e. segments that transcend borders, such as the elite global "jet set," or the "global teenager segment": Hassan and Katsanis, 1991) companies possessing a stable of local and international/global brands (Schuiling and 
Kapferer, 2004) - categorized as the "blurred boundary" brands described by Torelli and Stoner - should emphasize their global scope. However, when targeting domestic segments and cosmopolitan consumers, these firms should camouflage their ownership in order to preserve the benefits of perceived local resonance and authenticity. For example, in the Beer industry, $\mathrm{AB}$ InBev - a Belgian-based conglomerate that is the world's largest brewer[7] - goes to great lengths to emphasize the original source country of the brands in its stable, even for those that are sold around the world: Stella Artois as Belgian, Corona as Mexican, Budweiser as American, and Alexander Keith's as Canadian and so forth (Winit et al., 2014).

Consumers' judgments of authenticity and geographical provenance flow from several criteria, including perceptions regarding uniqueness, originality, craftsmanship and use of locally sourced materials, aesthetics and connections to cultural/historical aspects; in addition to the attestations of authenticity implicitly (e.g. symbolic imagery) or explicitly ("Made in__, geographical indicators) concocted by the brand's producers or vendors on signage, product packaging and in communication appeals (Keller, 1993; Chhabra, 2005). AB InBev's Alexander Keith's brand uses a Canadian wildlife icon, includes the slogan "The Pride of Nova Scotia" and prominently indicates that the beer has been brewed in Halifax (the largest city of the Canadian province of Nova Scotia) since 1820, at "Canada's Oldest Brewery"[8], while making no reference anywhere on the product to its foreign ownership or parent brand.

Linking consumers' responses to GCC to their psychological consequences is an important extension of our work and opens up fruitful research directions. The degree of identity salience in the context of assimilation, separation, marginalization, glocalization and creolization allows for a nuanced understanding of consumers' embrace of multiple converging and conflicting identities, depending on the consumption context. In line with Levitt's (1983) proposition of a homogenous GCC, consumer assimilation underlines consumers' global identities (i.e. consumers' recognitions of global commonalities and identifications with humankind; see Bartsch et al., 2016 for a review), as a driver of product/brand choice. The literature provides some evidence corroborating this response (e.g. Guo 2013; Tu et al., 2012; Magnusson et al., 2015), but, as we argue in our original paper, this response (assimilation) to globalization - and to some extent, the other patterns as well - is more vacillating and context specific rather than absolute.

Consumer separation occurs when individuals retreat into the safety of their ethnic, national or even regional cultures as a retort to advancing globalization. This entails the strengthening of parochial (i.e. local, ethnic, religious, national and regional) identities which are rooted in ethnicity, specific geographic locations or a spiritual entity, while rebuffing the GCC. Only a handful of studies have examined this pattern of cultural adjustment (e.g. Cleveland et al., 2013; Micevski et al., 2018). Consequently, insights into the processes and evolution of consumer separation are tentative, and this area is badly in need of further investigation (Ghemawat, 2017). Separation reveals trepidations about how GCC entails cultural colonialism (and potentially the fear of local brands being supplanted by global ones), thus provoking tribalism, reaffirmation, fundamentalism and neo-ethnicism (and its marketplace corollaries, such as consumer ethnocentrism: Shimp and Sharma, 1987).

With consumer marginalization, however, there is no such championing of the local or traditional culture. Rather, in the context of globalization, marginalization comes about through estrangement with both the traditional culture[9] as well as with the GCC. Marginalization may be due to an inability to navigate or reconcile the seemingly intractable tensions arising when globalization intermingles with local traditions. In such cases, consumers may seek affirmation with close-knit, often counter-culture social entities (Kozinets and Handelman, 2004) while rejecting adherence to broader, geographically based identities (i.e. ethnic, national, pan-regional or global identities). Social media and other advancements in telecommunications - one of the five horsemen of global cultural flows, 
IMR

36,4

602

labeled by Appadurai (1990) as mediascapes - facilitate such embryonic communities to perpetuate on a global scale. Paradoxically these social entities will come to influence the same GCC that they are railing against, should their marginalized traits become appropriated and modified by the mainstream.

Consumer glocalization signifies the comingling of global and local cultural identities Aspects of GCC are appropriated and indigenized by infusing local cultural elements. The extant literature points toward consumers embracing both global and local identities, and responding favorably to both global and local brands. The glocally engaged, youthful consumer represents one such target group: "global" in certain circumstances while "local" in other respects (Kjeldgaard and Askegaard, 2006; Strizhakova et al., 2012; Cleveland et al., 2013).

The final broad response to the globalization vortex, consumer creolization, is possibly the likeliest long-term aftermath of glocalization, yet, it is the least understood response. Mirroring the processes that had underlain the development of numerous "New World" national cultures[10], the switching between and comingling of various cultural identities and accompanying rituals are progressively transmuted into recognizably unique and creolized cultures, each with their own associated lifestyles, behaviors and artifacts (products). The topic has attracted qualitative researchers using exploratory, inductive approaches (e.g. Cayla and Eckhardt, 2008; Hung et al., 2007; Askegaard et al., 2005; Gessner and Schade, 1990). Large-scale quantitative studies on consumer creolization arising from globalization are scarce, and to our knowledge, cross-national, comparative investigations are non-existent. This state of affairs is no doubt due to the comparatively sluggish evolvement of creolized lifestyles and products, and the challenges in delineating and contrasting nascent creolizing cultural movements against the backdrop of global, local and glocal consumption communities.

All told, probing the cultural origin of brands - regardless of perceptual reach and consequential labeling as global, foreign or local - and conceiving consumers' location- and cultural-based identities as both antecedents of and responses to GCC, represent promising avenues for future investigations.

\section{Peter Magnusson and Stanford Westjohn - "Advancing global consumer culture research"}

In an astute and compelling commentary piece, Magnusson and Westjohn remind us that global brands are not nearly as dominant in terms of market share as one might expect, and we agree. That said, many product categories, such as automobiles, consumer electronics and luxuries have been global in scope for decades. Increasingly other categories, some long thought of as being relatively impervious to globalization, such as fashions, foodstuffs and financial services, are witnessing early stages of globalization. Many local brands - even those that do not aspire to expand outside their domestic markets - will have to adapt their marketing strategies in anticipation of or in response to competitors from abroad. As is true for domestic consumer segments, not all members of prototypically global consumer segments will want needs satisfied the same way (i.e. with the same product), all of the time. This means that the variability and selection currently available at the local level will be replicated and probably intensified at the global level. Our previous example of global consolidation in the beer industry is apt, where local brands and national-/parochial-identity positioning strategies are being retained even as these brands are distributed globally. This bears witness to the simultaneous forces of convergence and divergence occurring at the industry, brand and consumer levels. One could argue that retaining geographic-specific positionings - such as France and Champagne (province) associations articulated by l'Oréal and Dom Perignon, respectively - is essential for appealing to global consumer segments while avoiding the commodity trap (Quelch, 2007). The latter describes cases whereby 
product alternatives are essentially seen as commodities by consumers and have thus fallen into purely price-based competition.

Magnusson and Westjohn (2019) quite correctly underline the practical convenience and sometimes necessity of using the nation-state as the basis for market segmentation. Indeed, for many products the legal framework guides adaptation of the marketing mix (e.g. safety standards, advertising requirements, import taxes, language, etc.). However, from a positioning standpoint (i.e. in terms of focusing on the intangible aspects of brand image and promise), there are cases in which the nation-state may play a subordinate role, relative to cultural entities larger and smaller than the nation-state, which should increasingly be accorded greater emphasis. Even within geographically confined nations (e.g. the Netherlands, Belgium or Austria) there is much diversity and some evidence that consumer behaviors are not necessarily converging at the country level, in terms of lifestyles and brand/product preferences (Micevski et al., 2018). We advocate that marketers should target consumer groups that exhibit consistency in terms of their responses to marketing strategies, perhaps irrespective of their geographical propinquity. Deterritorialization, as one of the facets of GCC, promotes the dissemination of consumption preferences across the globe (Appadurai, 1990). As more consumer groups are decoupled from their geographical origins, marketers may position their brands products to different groups in different places as being neither being global, foreign or local per se (Alden et al., 1999), but as inherently culture-specific consumer artifacts (in the broader sense of culture representing a set of shared norms and values among a group). Positioning from a consumption subculture basis (Schouten and McAlexander, 1995) provides marketers with an alternative window of opportunity, to look beyond the old paradigm of standardization across borders vs adaption at the nation-state level. Beyond the examples raised in our essay on GCC (e.g. Cosplay, football or micro-breweries), we can imagine other culture-specific groups that would be appealing target segments. At the most basic level, Schwartz (1992) identifies a set of basic human values that are shared across major cultures and countries, i.e. openness to change, self-enhancement, conservation and self-transcendence. These represent valuable target market characteristics upon which brands could be positioned in global markets, e.g. insurance companies focusing on security and tradition, sports brands focusing on achievement, beauty brands focusing on empowerment and charities focusing on benevolence. To this end, recent research has sought to uncover the psychological determinants of various cultural outgroup orientations, such as cosmopolitanism and xenocentrism (Cleveland and Balakrishnan, 2018).

To summarize, Magnusson and Westjohn (2019) offer important extensions to our work by reminding us that global brands are not only defined by reach and strength (i.e. market share) and that practicalities often guide the composition of the marketing mix in which the nation-states remain an important entity for segmentation. We encourage research to investigate brand globalness, not as merely as a function of brands' awareness and reach across borders, but from the perspective of brands' positioning strategies, in terms of pursuing consumer groups that go beyond the nation-state.

\section{Concluding remarks}

To summarize, the three comment pieces provide compelling arguments that build upon our initial article. First, while we do not fully agree with de Mooij's (2019) comments on the absence of GCC or her depiction of GCC as merely a "fairy tale," she reiterates several crucial arguments hinting at a paradigm shift for the research domain. As stated in our piece, the character of GCC - or better still, its permutations - is "progressively shifting from West to East, as the planet's relative economic epicenter once again swings back to the Orient." These transmutations of GCC are evidently important for theory, research and practice.

Second, as discussed by Torelli and Stoner (2019), globalization and the progression of GCC have substantive implications for the management of global, local, regional or culture-specific 
products/brands. Studying the identity-relevant aspects of consumers' responses to GCC is vital for advancing what currently amounts to a relatively meager field of knowledge.

Third, Magnusson and Westjohn (2019) provide evidence that counters the "myth" that global brands are always dominant in terms of strength and market share. Indeed, for many product sectors, consumers are able to select from numerous global, foreign and domestic products/brands. Increasingly, these options - even those that are inextricably tied to a particular city or region (e.g. Manchester United F.C., Kentucky Bourbon) are desired by consumers living in places far from their origins. Notwithstanding the fact that the nation-state remains an important classification variable that guides strategy and informs consumer choice, marketers should appreciate the possibilities offered by subculture positioning strategies, as a means of effectively targeting diverse groups of consumers regardless of geography.

Mark Cleveland

DAN Management \& Organizational Studies, The University of Western Ontario, London, Canada, and

\author{
Fabian Bartsch \\ Marketing and Negotiation (LEM - CNRS 9221), \\ IESEG School of Management - Paris la Défense Campus, Paris, France
}

\title{
Notes
}

1. At the beginning of the nineteenth century, the French government implemented policies with the end goal of eradicating minority and regional languages, such as Occitan and Brittany, spoken in France (Labouysse, 2007).

2. www.asiapacific.ca/sites/default/files/filefield/researchreportv7.pdf (accessed November 23, 2018.)

3. www.fin.gov.on.ca/en/economy/demographics/census/cenhil6-8.html (accessed November 23, 2018).

4. http://worldpopulationreview.com/world-cities/dubai-population/ (accessed November 23, 2018).

5. www.brookings.edu/blog/the-avenue/2018/03/14/the-us-will-become-minority-white-in-2045census-projects/ (accessed November 23, 2018).

6. Most of which are Muslim, from Central Asian countries including former republics of the Soviet Union. www.bloomberg.com/news/features/2017-03-14/russia-s-alternative-universe-immigrantswelcome (accessed December 17, 2018).

7. www.ab-inbev.com/our-brands.html (accessed November 26, 2018).

8. www.alexanderkeithsbrewery.com/ (accessed January 4, 2019).

9. Which historically was often due to the extirpation of a tribe by a dominant culture, bereaving the former tribe's members of a cultural nexus.

10. Such as that of Mexico, forged from an uneven mixture of Spanish, indigenous and other ethnic and religious ingredients, and progressively shaped by evolving ecological, political, class and economic circumstances (Diaz-Guerrero, 1976).

\section{References}

Alden, D.L., Steenkamp, J.-B.E.M. and Batra, R. (1999), "Brand positioning through advertising in Asia, North America, and Europe: the role of global consumer culture", Journal of Marketing, Vol. 63 No. 1, pp. 75-87.

Appadurai, A. (1990), "Disjuncture and difference in the global cultural Economy", Theory, Culture \& Society, Vol. 7 Nos 2-3, pp. 295-310. 
Askegaard, S., Arnould, E.J. and Kjeldgaard, D. (2005), "Postassimilationist ethnic consumer research: qualifications and extensions", Journal of Consumer Research, Vol. 32 No. 1, pp. 160-170.

Bartsch, F., Riefler, P. and Diamantopoulos, A. (2016), "A taxonomy and review of positive consumer dispositions toward foreign countries and globalization”, Journal of International Marketing, Vol. 24 No. 1, pp. 82-110.

Ben-Amos, D. (1971), "Toward a definition of folklore in context", The Journal of American Folklore, Vol. 84 No. 331, pp. 3-15.

Berry, J.W. (1997), “Immigration, acculturation, and adaptation”, Applied Psychology, Vol. 46 No. 1, pp. 5-34.

Brewer, P. and Venaik, S. (2012), "On the misuse of national culture dimensions", International Marketing Review, Vol. 29 No. 6, pp. 673-683.

Cayla, J. and Eckhardt, G.M. (2008), "Asian brands and the shaping of a transnational imagined community", Journal of Consumer Research, Vol. 35 No. 2, pp. 216-230.

Chhabra, D. (2005), "Defining authenticity and its determinants: toward an authenticity flow model", Journal of Travel Research, Vol. 44 No. 1, pp. 64-73.

Cleveland, M. and Balakrishnan, A. (2018), "Appreciating vs venerating cultural outgroups: the psychology of cosmopolitanism and xenocentrism", International Marketing Review, available at: https://doi.org/10.1108/IMR-09-2018-0260

Cleveland, M. and Bartsch, F. (2019), "Global consumer culture: epistemology and ontology", International Marketing Review.

Cleveland, M. and Laroche, M. (2012), "Becoming and being a cosmopolitan consumer", in Prince, M. (Ed.), Consumer Cosmopolitanism in the Age of Globalization, Business Expert Press, New York, NY, pp. $51-100$.

Cleveland, M., Laroche, M. and Hallab, R. (2013), "Globalization, culture, religion, and values: comparing consumption patterns of Lebanese Muslims and Christians", Journal of Business Research, Vol. 66 No. 8, pp. 958-967.

de Mooij, M. (2019), "Fairy tales of global consumer culture in a polarizing world", International Marketing Review.

Diaz-Guerrero, R. (1976), Psychology of the Mexican: culture and personality, University of Texas Press, Austin, TX.

Dimofte, C.V., Johansson, J.K. and Ronkainen, I.A. (2008), "Cognitive and affective reactions of US consumers to global brands", Journal of International Marketing, Vol. 16 No. 4, pp. 113-135.

The Economist (2018), "The Chinese century: well under way”, Economist, p. 85.

Gessner, V. and Schade, A. (1990), "Conflicts of culture in cross-border legal relations: the conception of a research topic in the sociology of law", Theory, Culture \& Society, Vol. 7 Nos 2-3, pp. 253-277.

Ghemawat, P. (2017), "Globalization in the age of Trump”, Harvard Business Review, Vol. 95 No. 4, pp. 112-123.

Guo, X. (2013), "Living in a global world: influence of consumer global orientation on attitudes toward global brands from developed versus emerging countries", Journal of International Marketing, Vol. 21 No. 1, pp. 1-22.

Hassan, S.S. and Katsanis, L.P. (1991), "Identification of global consumer segments: a behavioral framework", Journal of International Consumer Marketing, Vol. 3 No. 2, pp. 11-28.

Hofstede, G. (2001), Culture's Consequences: Comparing Values, Behaviors, Institutions and Organizations Across Nations, Sage, London.

Hung, K.H., Li, S.Y. and Belk, R.W. (2007), "Glocal understandings: female readers' perceptions of the new woman in Chinese advertising", Journal of International Business Studies, Vol. 38 No. 6, pp. 1034-1051.

Keller, K.L. (1993), “Conceptualizing, measuring, and managing customer-based brand equity”, Journal of Marketing, Vol. 57 No. 1, pp. 1-22. 
IMR

36,4

Kjeldgaard, D. and Askegaard, S. (2006), "The glocalization of youth culture: the global youth segment as structures of common difference", Journal of Consumer Research, Vol. 33 No. 2, pp. 231-247.

Kozinets, R.V. and Handelman, J.M. (2004), "Adversaries of consumption: consumer movements, activism, and ideology”, Journal of Consumer Research, Vol. 31 No. 3, pp. 691-704.

Labouysse, G. (2007), Histoire de France: l'imposture! mensonges et manipulations de l'histoire officielle (French History is an Imposture! Lies and Manipulations of Official History), Institut d'Etudes Occitanes, Puylaurens.

Levitt, T. (1983), “The globalization of markets”, Harvard Business Review, Vol. 61 No. 3, pp. 92-102.

McSweeney, B. (2013), "Fashion founded on a flaw: the ecological mono-deterministic fallacy of Hofstede, GLOBE, and followers”, International Marketing Review, Vol. 30 No. 5, pp. 483-504.

Magnusson, P. and Westjohn, S.A. (2019), “Advancing global consumer culture research”, International Marketing Review.

Magnusson, P., Westjohn, S.A. and Zdravkovic, S. (2015), "An examination of the interplay between corporate social responsibility, the brand's home country, and consumer global identification", International Marketing Review, Vol. 32 No. 6, pp. 663-685.

Micevski, M., Halkias, G. and Herz, M. (2018), "Multiple consumer identities and the crossover effect of the EU identity in predicting domestic and foreign product preferences", Journal of Business Research.

Özsomer, A. (2012), "The interplay between global and local brands: a closer look at perceived brand globalness and local iconness", Journal of International Marketing, Vol. 20 No. 2, pp. 72-95.

Quelch, J. (2007), "How to avoid the commodity trap", Harvard Business Review, Vol. 12, December, pp. 34-38.

Renan, E. (1882/2002), "What is a nation?”, in Woolf, S. (Ed.), Nationalism in Europe: From 1815 to the Present, Routledge, London, pp. 54-66.

Schouten, J.W. and McAlexander, J.H. (1995), "Subcultures of consumption: an ethnography of the new bikers", Journal of Consumer Research, Vol. 22 No. 1, pp. 43-61.

Schuiling, I. and Kapferer, J.-N. (2004), "Real differences between local and international brands: implications for international marketers", Journal of International Marketing, Vol. 12 No. 4, pp. 97-112.

Schwartz, S.H. (1992), "Universals in the content and structure of values: theoretical advances and empirical tests in 20 countries", in Zanna, M. (Ed.), Advances in Experimental Social Psychology, Vol. 25, Academic Press, Orlando, FL, pp. 1-65.

Shimp, T.A. and Sharma, S. (1987), "Consumer ethnocentrism: construction and validation of the CETSCALE”, Journal of Marketing Research, Vol. 24 No. 3, pp. 280-289.

Strizhakova, Y., Coulter, R.A. and Price, L.L. (2012), "The young adult cohort in emerging markets: assessing their glocal cultural identity in a global marketplace", International Journal of Research in Marketing, Vol. 29 No. 1, pp. 43-54.

Torelli, C. and Stoner, J. (2019), "Global consumer culture: consequences for consumer research", International Marketing Review.

Tu, L., Khare, A. and Zhang, Y. (2012), “A short 8-item scale for measuring consumers' local-global identity", International Journal of Research in Marketing, Vol. 29 No. 1, pp. 35-42.

Venaik, S. and Brewer, P. (2013), "Critical issues in the Hofstede and GLOBE national culture models", International Marketing Review, Vol. 30 No. 5, pp. 469-482.

Winit, W., Gregory, G., Cleveland, M. and Verlegh, P. (2014), "Global vs. local brands: how home country bias and price differences impact brand evaluations", International Marketing Review, Vol. 31 No. 2, pp. 102-128. 